професійним спрямуванням)» реалізовувати потенціал своєї дисципліни щодо формування професійних цінностей курсантів;

- цілеспрямоване засвоєння значущих для професійної діяльності умінь і навичок: постійне збагачення пам'яті, громадянського мислення, вироблення свідомого ставлення до навчання, самоосвіти;

- удосконалення управління процесом формування професійних цінностей на заняттях з англійської мови (за професійним спрямуванням).

Ураховуючи те, що розвиток професійних цінностей курсантів морських навчальних закладів повинен відбуватись у три етапи і сприяти формуванню в них несуперечливої системи ціннісних орієнтацій, можна зробити висновок, що впровадження цих етапів на заняттях 3 англійської мови (за професійним спрямуванням) 3 урахуванням визначених психолого-педагогічних умов, дозволить курсантам гармонійно поєднувати патріотичні, національні та інтернаціональні почуття, ставитись 3 повагою до цінностей інших народів у своїй професійній діяльності, а отже, сприятиме найбільш ефективному формуванню професійних цінностей майбутніх морських фахівців.

Перспективу подальших досліджень убачаємо у виявленні необхідних методів і форм формування професійних цінностей курсантів у процесі вивчення англійської мови (за професійним спрямуванням).

\title{
Література
}

1. Бех І. Д.Виховання особистості. К. 2. «Особистісно орієнтований підхід: науково-практичні засади / І. Д. Бех. - К. : Либідь, 2003. - 320 с. 2. Бодалев А. А. Вершина в развитии взрослого человека. Быть профессионалом в психологии - это обязательно [Электронный ресурс]/ А. А. Бодалев. - Режим доступа: http: //hpsy.ru/public/x797.htm 3. Кудрявцева В. Ф. «Welcome Aboard». Student's Book. - Херсон: Грінь Д. С. - 2013. - 220 с. 4. Пимошенко А. «Безопасность мореплавания. Понять - значит спастись» / А. Пимошенко. - Калининград, 2003. $320 \mathrm{c}$.

УДК 004.912

Павло Мерзликін, Наталя Хараджсян

\section{РОЗРОБЛЕННЯ ШАБЛОНУ ОФОРМЛЕННЯ ПОЯСНЮВАЛЬНОЇ ЗАПИСКИ КУРСОВОЇ РОБОТИ ЗАСОБАМИ ХМАРНИХ ТЕХНОЛОГІЙ}

Мерзликін П. В., Хараджян Н. А. Розроблення шаблону оформлення пояснювальної записки курсової роботи засобами хмарних технологій.

У статті розглянуто можливість створення шаблону оформлення курсової роботи засобами хмарних технологій, що полегшить роботу над оформленням тексту згідно 3 висунутими до нього вимогами. Шаблон також може бути адаптований для використання в інших вищих навчальних закладах та для оформлення тексту кваліфікаційної роботи.

Ключові слова: шаблон, пояснювальна записка, хмарні технології, системи комп'ютерної верстки, LaTeX.

Мерзликин П. В., Хараджян Н. А. Разработка шаблона оформления пояснительной записки курсовой работы средствами облачных технологий.

В статье рассматривается возможность создания шаблона оформления курсовой 
работы средствами облачных технологий, который упростит работу над оформлением текста согласно предъявляемых к нему требований. Шаблон также может быть адаптирован для использования в других высших учебных заведениях и для оформления текста квалификационной работы.

Ключевые слова: шаблон, пояснительная записка, облачные технологии, системы компьютерной верстки, LaTeX.

Merzlykin P.V., Haradzhian N. A. The development of a typographic template for course project paper by means of cloud computing.

The paper discusses the possibility of creating a typographic template for course project paper by means of cloud computing which should simplify the text formatting according to the requirements. The template may also be adapted for use in other higher education institutions and for formatting the text of graduation paper.

Keywords: template, course project paper, cloud computing, document markup language, LaTeX.

Потреби суспільства та індивідуальні потреби людини весь час розвиваються, що спонукає до постійного еволюціонування галузі інформаційно-комунікаційних технологій. Збільшення кількості програмного забезпечення різного призначення та необхідність використовувати все більше обчислювальних ресурсів сприяє появі нової технології, що надає користувачам Інтернету доступ до комп'ютерних ресурсів сервера і використання програмного забезпечення як онлайн-сервіса. Такі технології отримали назву хмарних технологій. За останні кілька років концепція хмарних технологій (хмарних обчислень) стала провідною в галузі інформаційнокомунікаційних технологій. Хмарні технології поступово входять до всіх сфер діяльності суспільства, зокрема й освіти. Відповідно до хмарного підходу адекватно змінюються і засоби інформаційно-комунікаційних технологій.

Згідно 3 «Програмою інформатизації та комп’ютеризації навчального процесу» [3] від 2004 року необхідно готувати студентів із використанням сучасних технологій навчання, до яких відносять хмарні технології. Згодні із цим положенням вітчизняні фахівці Е. Аблялімова, В. Биков, Л. Меджитова, С. Сейветлісва, 3. Сейдаметова, С. Семеріков, В. Темненко, Ю. Триус, О. Чорна М. Шишкіна та інші. Вони вважають, що одним із можливих сучасних шляхів розв'язання проблеми підвищення якості освіти є впровадження хмарних технологій, що на сучасному етапі розвитку ІКТ стають технологічною основою підготовки компетентних, мобільних фахівців будь-якої галузі, створюють умови для реалізації мобільного навчання сучасного напряму розвитку дистанційного навчання із застосуванням ІКТ-засобів нового покоління, що своїми користувальними властивостями відображають особливості будови, функції і параметри нової мережевої хмарної ІКТ-інфраструктури (iPAD, imPad, iPad-Hibrid, Reder, iPhone, SmartPhone, iPod, мультимедійні дошки 3 інтернет-доступом тощо).

До головних переваг використання хмарних технологій можна віднести те, що вони надають певні послуги: програмне забезпечення як сервіс (SaaS: Software-as a Service), платформа як сервіс (PaaS: Platform as a Service), інфраструктура як сервіс (IaaS: Infrastructure as a Service), дані як послуга (DaaS: Desktop as a Service), робоче місце як послуга (Workspace as a Service, WaaS), апаратне забезпечення як послуга (HaaS: Hardware as a service) тощо.

Проте хмарні технології можуть бути застосовані не лише для організації 
традиційного аудиторного навчання, а й використані як системи підтримки дистанційного та мобільного навчання, мережні системи комп'ютерної математики, мережні системи документообігу, системи організації спільної роботи тощо.

Mema cmammi- розглянути можливість використання засобів хмарних технологій для розроблення шаблону оформлення пояснювальної записки курсової роботи.

Згідно 3 «Положенням про організацію навчального процесу у вищих навальних закладах» № 161 від 2.06.93 р. [2] курсові проекти (роботи) виконуються задля закріплення, поглиблення й узагальнення знань, одержаних студентами за час навчання, та їх застосування до комплексного вирішення конкретного фахового завдання.

Протягом навчання на технічних напрямах підготовки та спеціальностях студенти виконують 5-8 курсових робіт, що містять велику кількість математичного тексту. Значну частину роботи над курсовим проектом складає його оформлення згідно з висунутими вимогами. На цьому етапі виникає найбільша кількість проблем та помилок.

На сучасному етапі розвитку інформаційно-комунікаційних, зокрема хмарних, технологій з'явились і розвиваються засоби, що допомагають полегшити та спростити процес оформлення пояснювальної записки.

Створивши один раз шаблон роботи, так званий «скелет», можна використовувати його надалі у своїх роботах, просто наповнюючи текстом. У цьому можуть допомогти системи комп'ютерної верстки.

Найбільш популярною системою комп'ютерної верстки $є$ ТеХ [1] - система для верстки текстів та формул. Сам по собі ТеХ є спеціалізованою мовою програмування, якою пишуть видавничі системи, що на базі ТеХа являють собою пакет макровизначень певної мови. До макропакетів, створених на базі ТеХа, відносять: LaTeX, pdfTeX, XeTeX, LuaTeX, Omega (TeX), BibTeX, ABC (нотний запис). Кожен із них має своє спрямування й дозволяє ефективно розв'язувати задачі верстки тексту в різних галузях з урахуванням специфіки текстів.

Пакет LaTeX, створений Лесли Лампортом, дозволяє автоматизувати форматування та набір тексту, підготовку статей до подання у спеціалізовані математичні журнали, включаючи набір тексту кількома мовами, нумерацію розділів і формул, перехресні покликання, розміщення ілюстрацій і таблиць на сторінці, ведення бібліографії тощо. Тому доречно створити шаблон курсової роботи, використовуючи всі можливості LaTeX i тим самим полегшити роботу студентам та зробити зовнішній вигляд робіт уніфікованим та відповідним стандарту. LaTeX відокремлює зміст від оформлення документа. Тому, використавши шаблон, можна не приділяти увагу форматуванню тексту, а саме зосередитися на змісті й розкритті теми.

Створення курсової роботи засобами LaTeX має низку переваг:

- на відміну від пропріетарних систем верстки та текстових процесорів, LaTeX $€$ вільним програмним забезпеченням;

- абсолютно однаковий зовнішній вигляд готових сторінок у всіх операційних системах;

- достатньо один раз створити шаблон і використовувати його для всіх робіт;

- зручна робота зі складними математичними формулами;

- наявність гнучких засобів для роботи з логічною структурою тексту.

Є чотири базових стилі написання документа. Це: letter, article, report та book. Для написання курсової роботи найбільше підходить report. Документ 
ділиться на преамбулу і тіло. Преамбула містить інформацію про клас документа, використані пакети макросів, визначення макросів, автора, дату створення документа та іншу інформацію. Коментарі всередині LaTeX-скрипта ставляться через символ \%. Наприклад:

о вказуємо розмір аркуша, розмір шрифту і тип документа

$\backslash$ documentclass [a4paper, 12pt] \{report\}

lusepackage [utf8x] \{inputenc\}

о використовуємо українську мову з переносами

\usepackage [ukrainian] \{babel\}

Далі потрібно перерахувати потрібні пакети для документа: графічні, математичні тощо.

Оскільки це шаблон курсової роботи, то задаємо параметри сторінок згідно 3 вимогами, тобто геометрію аркуша:

\usepackage \{geometry\} о змінюємо поля сторінки;

Igeometry $\{$ left $=3 \mathrm{~cm}\} \%$ ліве поле

lgeometry $\{$ right $=1.5 \mathrm{~cm}\}$ о праве поле;

lgeometry $\{$ top $=2 \mathrm{~cm}\} \div$ верхне поле

lgeometry $\{$ bottom $=2 \mathrm{~cm}\}$ о нижне поле;

о інтервал між рядками 1.5;

$\backslash$ renewcommand $\{\backslash$ baselinestretch $\}$ \{1.25\}

Перейдемо до створення самого документа:

$\backslash$ begin $\{$ document\}

$\backslash$ input $\{$ Title\} о файл титульного аркуша;

$\backslash$ tableofcontents 응 зміст, який генерується автоматично

$\backslash$ end $\{$ document ;

Зовнішній файл Title.tex описує вигляд титульної сторінки курсової роботи. Оскільки зовнішній вигляд титульного аркуша цілком ідентичний для всіх курсових робіт, зручно винести його в окремий модуль, а на місцях змінюваних полів (прізвище, група, керівник тощо) вписати змінні (в LaTeX ïx можна реалізувати за допомогою механізму команд користувача). Тоді для генерації титульної сторінки достатньо буде лише заповнити поля такого вигляду:

\newcommand $\{\backslash$ ministry\}\{MIHICTEPCTBO ОСВITИ I НАУКИ УКРӒ̈нИ

\newcommand \{\institution\}\{ДЕРЖАВНИЙ ВИЩИЙ НАВЧАЛЬНИЙ ЗАКЛАД \\ <<КРИВОРІЗЬКИЙ НАЦІОНАЛЬНИЙ УНІВЕРСИТЕТ $>\backslash \backslash$ КРИВОРІЗЬКИЙ ПЕДАГОГІЧНИЙ ІНСТИТУТ \\\} назва ВНЗ

\newcommand \{\department\}\{Кафедра інформатики та прикладної математики\} \% назва кафедри

\newcommand \{\headOfDepartment\}\{шелевицький I.B.\} зав. кафедри

\newcommand $\{\backslash$ theme $\{$ РОЗРОБКА WЕВ-ПОРТАЛУ ГРОМАДСЬКИХ ОРГАНІЗАЦІЙ КРИВОГО РОГУ

$\backslash$ newcommand $\{\backslash$ sex $\{$ ж\} остать студента

$\backslash$ newcommand $\{\backslash$ faculty\} $\{$ ізико-математичного факультету оназва факультету

$\backslash$ newcommand $\{\backslash$ city\} Кривий Ріг\} оназва міста

$\backslash$ newcommand $\{\backslash$ group $\{I-10\}$ огрупа

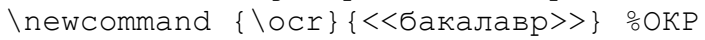

$\backslash$ newcommand $\{\backslash$ trainingDirection\}\{6.040302 Iнформатика* 
онапрям підготовки

Inewcommand \{\student\}\{Федоренко Олени Сергї̈нни 으 студента

\newcommand $\{\backslash$ chief $\{\kappa . \quad$. - M. н. Мерзликін П. В.\} окерівник роботи

LaTeX змушує автора тексту у будь-якій формі структурувати документ, інакше на виході буде згенеровано безформний потік тексту. У шаблоні курсової роботи найбільша структурна одиниця - це розділ, і зробити його можна за допомогою команди \section \{назва розділу\} . Далі текст логічно поділить на підрозділи, які в LaTeX позначаються природними англійськими словами:

$\backslash$ subsection $\{$ Підрозділ\};

\subsubsection \{Підпідрозділ\};

$\backslash$ paragraph $\{$ Пункт $\}$.

У самому тексті можна створювати абзаци, необхідно просто залишити порожній рядок.

Завдяки смисловій розмітці тексту зміст можна сформувати автоматично, написавши у потрібному місці команду:

$\backslash$ tableofcontents.

Щоб додати бібліографію, пишемо:

\addcontentsline

$\{$ toc $\}$ section $\}$

$\{\backslash$ tocsecindent \{Використані джерела\}

LaTeX зручний тим, що можна з легкістю вставляти та редагувати формули, що використовуються під час написання курсової роботи. Для цього використовують символи \$ \$, усередині яких уміщено саму формулу. Пара символів \$\$ \$ дозволяє розмістити формулу в окремому рядку. Набір формул у LaTeX відбувається швидше, ніж у текстових процесорах. Усі команди мають чітку лаконічну структуру та зручні для запам'ятовування.

У такий спосіб можна вставляти в текст таблиці та рисунки. LaTeX дозволяє автоматично нумерувати всі ці об'єкти та робити на них покликання, тобто під час видалення 3 документа формули або таблиці нумерація i покликання будуть оновлюватися.

Розглянемо створення шаблону титульної сторінки у хмарному середовищі www.writelatex.com. Цей засіб дозволяє працювати як зареєстрованим, так i незареєстрованим користувачам, у режимі он-лайн компілювати файли, отримувати документи у форматі pdf, зберігати їх в DropBox та організовувати спільну роботу науковців (рис. 1.). Однією із головних переваг хмарних технологій загалом, і систем комп'ютерної верстки зокрема, є використання web-браузерів для роботи з ними, що дозволяє не встановлювати спеціальне програмне забезпечення на власний комп'ютер. 


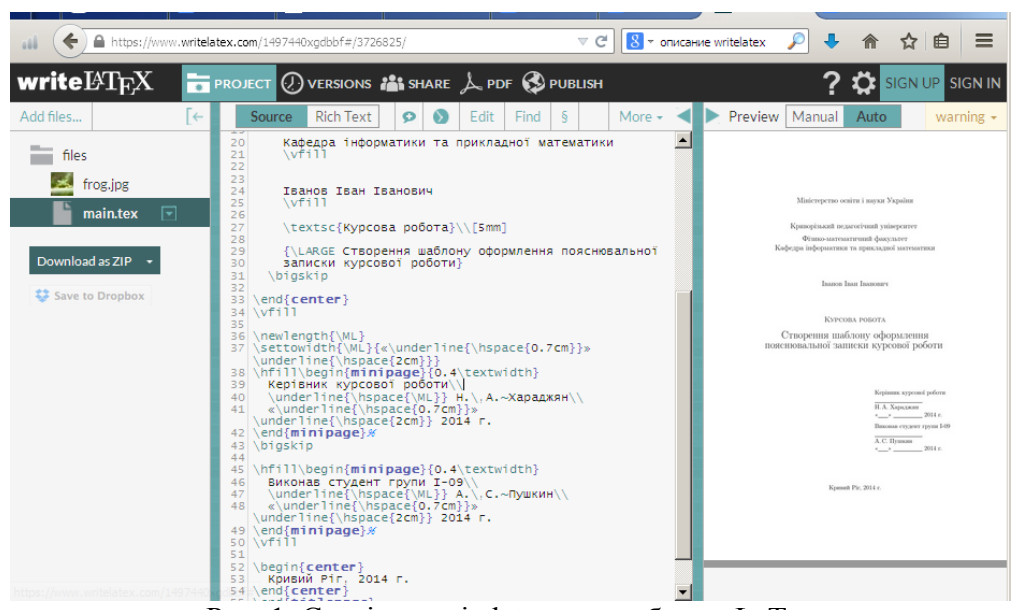

Рис. 1. Сторінка writelatex для роботи з LaTex

У статті розглянуто можливість створення шаблону оформлення пояснювальної записки курсової роботи засобами LaTeX, що відповідає вимогам, висунутим до іï оформлення. Практична значущість роботи полягає в тому, що пропонований шаблон компілюється за допомогою хмарних технологій та може в подальшому бути вдосконаленим і адаптованим для написання кваліфікаційних робіт.

\section{Література}

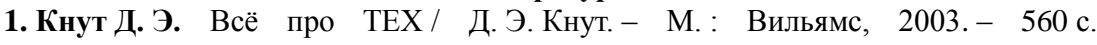
2. Положення про організацію навчального процесу у вищих навальних закладах: Наказ Міністерства освіти України № 161 від 2.06.93 р. [Електронний ресурс] // Режим доступу: http://zakon2.rada.gov.ua/laws/ show/z0071-93. 3. Про затвердження Державної програми інформатизації та комп'ютеризації вищих навчальних закладів I-II рівня акредитації на 2005-2008 роки : Постанова Кабінету Міністрів України № 1182 від 08.09.2004 р. [Електронний ресурс]// Режим доступу: http://zakon4.rada.gov.ua/laws/show/1182-2004-\%D0\%BF.

УДК 378.016: $78+159.962$

Вікторія Міщанчук

\section{ДІАГНОСТУВАННЯ РІВНІВ СФОРМОВАНОСТІ МУЗИЧНО-ВИКОНАВСЬКОЇ ПІДГОТОВКИ СТУДЕНТІВ ІНСТИТУТІВ МИСТЕЦТВ 3 ВИКОРИСТАННЯМ СУГЕСТИВНИХ ТЕХНОЛОГІЙ}

Міщанчук В. М. Діагностування рівнів сформованості музично-виконавської підготовки студентів інститутів мистецтв із використанням сугестивних технологій.

У статті розглядаються основні етапи діагностування рівнів сформованості музично-виконавської підготовки майбутніх учителів музики 3 використанням сугестивних технологій. 3'ясовано стан сформованості змістової системи використання сугестивних технологій у музично-виконавській підготовці студентів інститутів мистецтв відповідно до розроблених критеріїв і показників.

Ключові слова: майбутній учитель музики, музично-виконавська підготовка, сугестивна технологія, діагностування. 